\title{
Physiologicomathematical model for studying human exposure to organic solvents: kinetics of blood/tissue n-hexane concentrations and of 2,5-hexanedione in urine
}

\author{
L PERBELLINI, ${ }^{1}$ P MOZZO, ${ }^{2}$ F BRUGNONE, ${ }^{1}$ A ZEDDE ${ }^{1}$ \\ From the Institute of Occupational Medicine ${ }^{1}$ and Physical Health Service, ${ }^{2}$ Policlinico Borgo Roma, $37134-$ \\ Verona, Italy
}

ABSTRACT The physiologicomathematical model with eight compartments described allows the simulation of the absorbtion, distribution, biotransformation, excretion of an organic solvent, and the kinetics of its metabolites. The usual compartments of the human organism (vessel rich group, muscle group, and fat group) are integrated with the lungs, the metabolising tissues, and three other compartments dealing with the metabolic kinetics (biotransformation, water, and urinary compartments). The findings obtained by mathematical simulation of exposure to $n$-hexane were compared with data previously reported. The concentrations of $n$-hexane in alveolar air and in venous blood described both in experimental and occupational exposures provided a substantial validation for the data obtained by mathematical simulation. The results of the urinary excretion of 2,5-hexanedione given by the model were in good agreement with data already reported. The simulation of an exposure to $n$-hexane repeated five days a week suggested that the solvent accumulates in the fat tissue. The half life of n-hexane in fat tissue equalled 64 hours. The kinetics of 2,5-hexanedione $=$ resulting from the model suggest that occupational exposure results in the presence of large amounts of 2,5-hexanedione in the body for the whole working week.

Various mathematical models simulating the uptake, distribution, and excretion of hexogenous chemicals in the body have been proposed during the past decades.

They are useful in many fields of toxicology and medicine. Fiserova-Bergerova described a mathematical model for the kinetics of anaesthetic gases which has been extended to organic solvents. ${ }^{1}$ Other models have been used by Sato et al, ${ }^{2}$ Fernandez et $a l,^{3}$ and Droz et $a l^{4}$ to simulate the behaviour of industrial solvents in people occupationally or experimentally exposed. Many interesting data from which to prepare similar physiologicomathematical models have been reported by Fiserova-Bergerova. ${ }^{5}$

The pharmacokinetics of some antineoplastic drugs have also been reported by using differential equations integrated into a mathematical model which describes the probable movements of the substances in the body compartments. ${ }^{67}$ Ramsey and Andersen

Accepted 3 March 1986 proposed a physiologically based pharmacokinetic model to describe the behaviour of inhaled styrene in rats and to predict its kinetics in man. ${ }^{8}$

Droz suggested that the mathematical models simulating solvent pharmacokinetics after occupational exposure may be useful in establishing the "biological exposure index" of these products, in studying the individual parameters which are able to modify the solvent concentrations in the tissues of exposed people, and for further research into the relation between the body concentrations of the solvents and their toxic effects. ${ }^{9}$

A matter which has been insufficiently discussed in these mathematical models is that of the biotransformation of the inhaled gases. Recently Andersen et al obtained some interesting toxicokinetic descriptions of the metabolism of inhaled gases in animals ${ }^{10}$ and these results are useful to complete the basic data needed for the simulating models.

The present paper describes a mathematical model that integrates the data about the behaviour of sol- 
vents in the body compartments with the results of the kinetics of their metabolites. The results suggested by the model about the distribution of $n$-hexane in the body compartments and of its main metabolite (2,5-hexanedione) are compared with the data found in published reports and discussed in connection with the neurotoxic effects of these products.

\section{Materials and methods}

We prepared a mathematical model with the following eight compartments (fig 1).

(1) Lung compartment where the solvent arrives via inhalation and reaches a concentration that also depends on the solvent concentration in the alveolar air, in the arterial blood, and in the venous blood.

(2) Vessel rich tissue compartment (VRG) including the heart, brain, and kidney.

(3) Muscle tissue compartment (MG).

(4) Fat tissue compartment (FG).

(5) and (6) Liver tissue which includes two compartments: one relating to the input and output of $n$ hexane (catabolism of n-hexane) and the other relating to the synthesis and transfer of 2,5-HD.

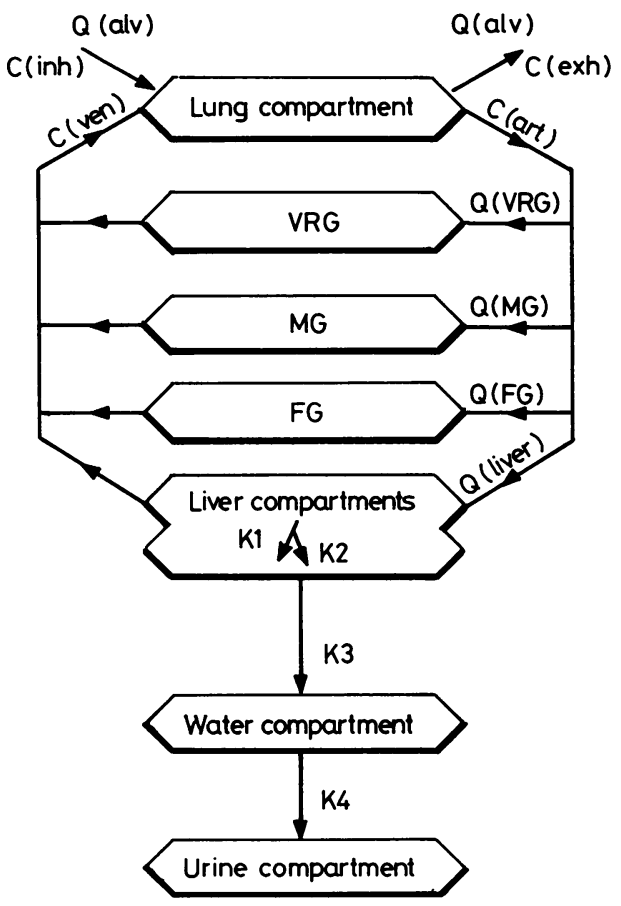

Fig 1 Diagram of the physiologicomathematical model used to simulate the pattern of distribution of n-hexane in the body and of 2,5-HD urinary excretion. Symbols and physiological parameters are reported in tables 1 and 2 and in text.
(7) Water compartment concerned with the body distribution of 2,5-HD.

(8) Urine compartment where 2,5-HD is excreted. No other routes of 2,5-HD excretion have been considered.

The symbols shown in fig 1 are defined in tables 1 and 2. All mathematical models describing the behaviour of solvents in the body are based on the two main hypotheses that: (1) the solvent concentration instantaneously reaches a balance between alveolar air and arterial blood (physiologically the balance is reached very quickly) and (2) the solvent concentration in venous blood is considered to be in constant and dynamic balance with the corresponding tissue concentrations.

The liver compartment is theoretically considered to be the only site at which the synthesis of metabolites takes place. The rate constants $(\mathrm{K})$ which describe the catabolism, synthesis, or transfer of the biotransformed products are considered to be first order.

Table 1 Physiological and kinetic parameters used in the model simulating human exposure to n-hexane. Percentage values of the total flow rate are shown in parentheses

\begin{tabular}{|c|c|c|}
\hline Volumes (l) & $\begin{array}{l}\text { Blood flow } \\
\text { (l/min) }\end{array}$ & $\begin{array}{l}\text { Tissue/blood } \\
\text { partition } \\
\text { coefficient) }\end{array}$ \\
\hline $\begin{array}{r}7 \cdot 1 \\
36 \cdot 3 \\
11 \cdot 5 \\
1 \cdot 7\end{array}$ & $\begin{array}{l}3.47(55 \%) \\
0.99(16 \%) \\
0.28(4.4 \%) \\
1.56(25 \%)\end{array}$ & $\begin{array}{c}5 \\
6 \cdot 2 \\
130 \\
6 \cdot 5\end{array}$ \\
\hline \multicolumn{3}{|c|}{ 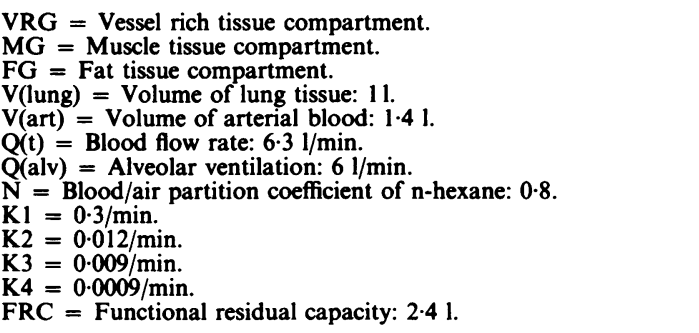 } \\
\hline
\end{tabular}

Table 2 Symbols and abbreviations used in describing the toxicokinetic model and in the mathematical equations

\begin{tabular}{|c|c|c|}
\hline C(i) & $=$ & Concentration in compartment (i) (mg/l). \\
\hline Q(i) & & Blood flow rate to compartment (i) (l/min). \\
\hline V(i) & $=$ & Volume of compartment (i) (l). \\
\hline C(art) & $=$ & Solvent concentration in arterial blood $(\mathrm{mg} / \mathrm{l})$. \\
\hline N(i) & $=$ & Tissue/blood partition coefficient. \\
\hline C(ven) & $=$ & Solvent concentration in venous blood $(\mathrm{mg} / \mathrm{l})$. \\
\hline A(lung) & $=$ & Amount of solvent in lung compartment (mg). \\
\hline C(lung) & $=$ & Solvent concentration in lung compartment $(\mathrm{mg} / \mathrm{l})$. \\
\hline C(inh) & $=$ & Environmental concentration of solvent (mg/l). \\
\hline C(exh) & $=$ & Solvent concentration in expired air $(\mathrm{mg} / \mathrm{l})$. \\
\hline $\mathbf{A}(1)$ & & $\begin{array}{l}\text { Amount of metabolite (2,5-HD) in metabolising } \\
\text { tissue group (liver compartment) (mg). }\end{array}$ \\
\hline $\mathbf{A}(\mathbf{w})$ & $=$ & $\begin{array}{l}\text { Amount of metabolite (2,5-HD) in the water } \\
\text { compartment }(\mathrm{mg}) \text {. }\end{array}$ \\
\hline $\mathbf{A}(\mathrm{u})$ & $=$ & Amount of metabolite (2,5-HD) in urine (mg). \\
\hline
\end{tabular}


PARAMETERS FOR THE MATHEMATICAL MODEL The following parameters are needed to work with the mathematical model: the volume and the blood flow to each compartment, the blood/air and tissue/blood solvent partition coefficients, and the rate constants for solvent biotransformation and for the behaviour of its metabolites in the body.

For the assignment of the volumes and the blood flows of the individual compartments we have used previously reported data ${ }^{112}$; these physiological parameters are listed in table 1.

Values for the solubility of n-hexane in blood and in human tissues (blood/air and tissues/blood partition coefficients) were taken from our experimental studies "in vitro" (table 1). ${ }^{13}$ The solubility data obtained in human tissues were similar to those found in rat tissues "in vivo,"14 apart from the liver/blood solubility which, in rats, increased throughout the exposure period.

The parameters of $n$-hexane biotransformation and of the distribution and excretion of 2,5-hexanedione were assigned according to reports or calculated from data obtained by us in workers exposed to the solvent or according to some iterative tests on the mathematical model.

Figure 1 shows both the tissue body compartmerits and the scheme that describes the catabolism of $n$ hexane in the metabolising tissues (disappearance of $\mathrm{n}$-hexane), the production of $2,5-\mathrm{HD}$ in the metabolising tissues (liver), and its transfer from the liver into the water compartment and into the urinary compartment. A similar method for metabolite studies was proposed by Wagner. ${ }^{15}$

The rate constant, $\mathrm{K} 1$, describes the disappearance of $n$-hexane, $K 2$ represents the constant rate of synthesis of 2,5-HD into the liver compartment, $\mathrm{K} 3$ is the rate constant describing the transfer of 2,5-HD from the liver into the hydric compartment, and $\mathrm{K} 4$ is the rate constant for the urinary excretion of the 2,5-HD.

The biotransformation rate of $n$-hexane is fast in the liver compartment at an environmental exposure of about $100 \mathrm{ppm}\left(360 \mathrm{mg} / \mathrm{m}^{3}\right)$. Hildebrand and Andersen who studied $\mathrm{n}$-hexane metabolism indirectly by measuring the disappearance of $n$-hexane from exposure cages regardless of the production of $\mathrm{n}$-hexane metabolites, ${ }^{16}$ found that the $\mathrm{V}$ max of the n-hexane metabolism could be estimated at 8.3 $\mathrm{mg} / \mathrm{kg} / \mathrm{h}$ and that the $\mathrm{km}$ corresponded to an environmental $\mathrm{n}$-hexane exposure of $163 \mathrm{ppm}\left(587 \mathrm{mg} / \mathrm{m}^{3}\right)$. In occupational exposure to $100 \mathrm{ppm}\left(360 \mathrm{mg} / \mathrm{m}^{3}\right)$ of $\mathrm{n}$-hexane, we can estimate an alveolar $\mathrm{n}$-hexane uptake of $0.6 \mathrm{mg} / \mathrm{kg} / \mathrm{h}$, which is less than one tenth the metabolism velocity ( $\mathrm{V}$ max) of $\mathrm{n}$-hexane in rats $(8 \cdot 3$ $\mathrm{mg} / \mathrm{kg} / \mathrm{h}) ;(\mathrm{n}$-hexane uptake $=\mathrm{Ci} \times \mathrm{R} \times \mathrm{VA} \times \mathrm{t} / \mathrm{kg}$ with $\mathrm{Ci}=$ environmental concentration $(360 \mu \mathrm{g} / \mathrm{l}), \mathrm{R}$ $=$ alveolar retention $(20 \%),{ }^{17} \mathrm{VA}=$ alveolar venti- lation $(10 \mathrm{l} / \mathrm{min}), \mathrm{t}=$ time in minutes, $\mathrm{kg}=$ body weight $(70 \mathrm{~kg}))$. In other words, assuming that $\mathrm{V}$ max in man is similar to that in rats, the amount of nhexane absorbed during an occupational exposure to $100 \mathrm{ppm}$ is much less than can be actually biotransformed. In experimental exposure only concentrations higher than $3600 \mathrm{mg} / \mathrm{m}^{3}$ seem to be able to saturate the metabolic activity of the rat liver. ${ }^{18}$

Bearing in mind all these considerations in the mathematical model we used a metabolising rate constant of n-hexane $\mathrm{K} 1$ equal to $0 \cdot 3$. A similar value was used by Ramsey and Andersen for the metabolising rate constant of styrene. ${ }^{8} \mathrm{~K} 4$ is the urinary excretion rate of 2,5-HD from the hydric compartment. Some data already published ${ }^{19}$ and other data collected by us from the urinary 2,5-HD kinetics in workers occupationally exposed to n-hexane, enabled us to estimate the mean half life of $2,5-\mathrm{HD}$ in the urine to be about 13-14 hours, which means a K4 near to 0.0009 .

Among the numerous products emerging from the metabolism of $n$-hexane in rat, rabbit, monkey, and man, 2- and 3-hexanols are the main urinary metabolites in animals, and 2,5-HD is the main urinary metabolite in man. ${ }^{2021}$ In experimental animals treated with $\mathrm{C} 14-$ hexane $^{22} 30-40 \%$ of the dose was eliminated as $14-\mathrm{CO}_{2}$ in the breath and $40-50 \%$ as unidentified metabolites in the urine. This suggests that $\mathrm{n}$-hexane is a highly metabolised compoun $(70-90 \%)$. Provided that the urinary n-hexane metabo olites actually identified in man turn out to corre? spond only to about $1-2 \%$ of the absorbed $n$ hexane, ${ }^{19}$ it follows that 2,5-HD represents only a small amount of the biotransformed $n$-hexane and we used a rate constant of 2,5-HD synthesis which is about one thirtieth of that for $n$-hexane catabolism $(\mathrm{K} 2=0.012)$.

$\mathrm{K} 3$ is the rate constant of the release of $2,5-\mathrm{HD}$ from the liver into the water compartment. We bore in mind that the highest point of the urinary excretion rate of 2,5-HD was reached three to four hours after the end of exposure both in animals and in man. ${ }^{1920}$ Moreover, the mean excretion of 2,5-HD in workers exposed to $360 \mu \mathrm{g} / 1$ of $\mathrm{n}$-hexane for eight hours was found to equal $2.8 \mathrm{mg}$ in 24 hours. ${ }^{19}$ On the basis of these considerations and after iterative estimations on the mathematical model, we assumed that $\mathrm{K} 3$ equalled $0 \cdot 009$. The set of differential equations used in the model is given in the appendix.

\section{Results}

The venous blood concentrations of $n$-hexane after exposures to 360 and $720 \mathrm{mg} / \mathrm{m}^{3}$ for four hours calculated from the model are shown in figure 2 . The open 


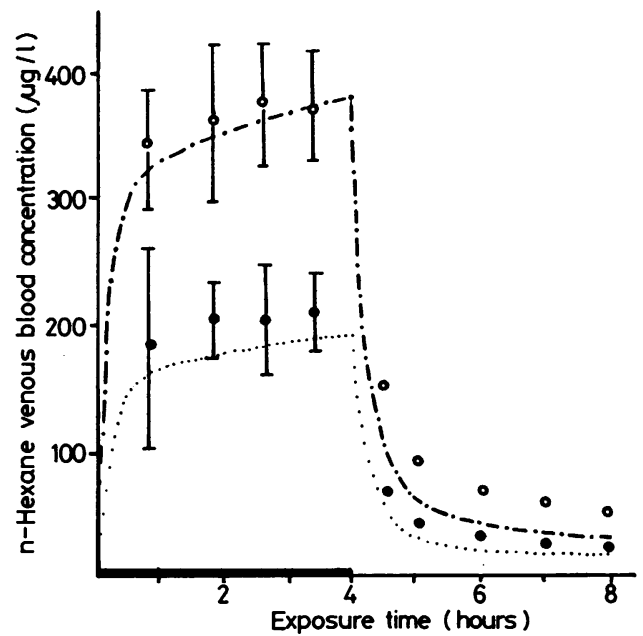

Fig 2 Venous blood concentrations of n-hexane during and after exposure to the solvent. Data suggested by the mathematical model (......... exposure to $360 \mathrm{mg} / \mathrm{m}^{3}$; ....... exposure to $720 \mathrm{mg} / \mathrm{m}^{3}$ ) and data found by Veulemans et al $^{23}$ (O: exposure to $360 \mathrm{mg} / \mathrm{m}^{3}$; O: exposure to $\left.720 \mathrm{mg} / \mathrm{m}^{3}\right)$.

and filled circles are data reported by Veulemans $e t$ al during and after experimental human exposures. ${ }^{23}$ The venous blood concentrations of $n$-hexane in people exposed to $720 \mathrm{mg} / \mathrm{m}^{3}$ for four hours, with a mean lung ventilation of $10.4 \mathrm{l} / \mathrm{min}$, ranged, on average, between 334 and $368 \mu \mathrm{g} / \mathrm{l}$ during exposure and were similar to those suggested by our model. The venous concentrations obtained from the simulated exposure to $360 \mathrm{mg} / \mathrm{m}^{3}$ were about $10 \%$ lower than those found by Veulemans et al. ${ }^{23}$

Figure 2 also shows the trend of the blood $n$-hexane concentrations after the end of exposure. The experimental values found after the end of exposure ${ }^{23}$ fall a little more slowly than those given by the model.

Figure 3 shows the trend of the n-hexane concentrations in venous blood, in alveolar air, and in the various compartments (apart from fat), when a mean exposure to n-hexane equal to $360 \mathrm{mg} / \mathrm{m}^{3}$ for a workshift (four hours in the morning and four in the afternoon) is simulated. After the beginning of exposure, the n-hexane concentrations rise rapidly: within $\mathbf{3 0}$ minutes tissue concentrations are more than $70 \%$ of the concentration that they will reach at the end of the workshift (only muscle tissues need a longer time to approach these levels because of their large volume).

During the midday work break (one hour), the nhexane concentrations in venous blood, in alveolar air, in the VRG, and in the liver quickly fall to 5-18\% of the value found at the end of the first four hours of exposure. When work begins again, the blood and tissue concentrations quickly return to a high level

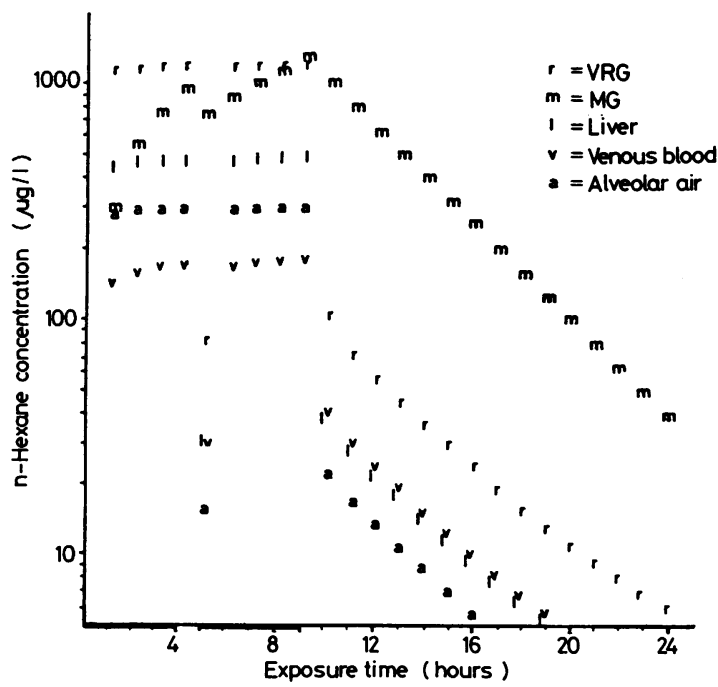

Fig 3 -Hexane concentrations in various compartments suggested by model: exposure to solvent equals $360 \mathrm{mg} / \mathrm{m}^{3}$ for four + four hours with a workbreak lasting one hour.

and at the end of exposure, the alveolar air, venous blood, VRG, and MG show n-hexane levels equal respectively to $82 \%, 62 \cdot 5 \%, 82 \cdot 8 \%$, and $67 \cdot 3 \%$ of the saturation level. At the end of exposure the n-hexane concentration in venous blood corresponds to $182 \mu \mathrm{g} / \mathrm{l}$.

On many occasions we have checked the n-hexane concentrations in the workplaces of numerous workers and simultaneously obtained venous blood samples at the end of exposure to analyse the solvent concentration; fig 4 summarises our experience in this field. The close relation between the two parameters suggests that an exposure to $360 \mathrm{mg} / \mathrm{m}^{3}$ of $\mathrm{n}$-hexane corresponds to a mean blood concentration of 176 $\mu \mathrm{g} / \mathrm{l}$. As may be seen, the result suggested by the model $(182 \mu \mathrm{g} / \mathrm{l})$ is similar to that found in the workers occupationally exposed to $n$-hexane.

The alveolar concentrations of $n$-hexane (which are always in constant balance with arterial blood concentrations) 60 minutes from the beginning of exposure, correspond to $77.5 \%$ of the exposure concentrations and increase to $83.3 \%$ at the end of exposure (fig 3). These data confirm our previous research on workers ${ }^{17}$ and suggest that the alveolar concentration (apart from a brief period after the beginning of exposure) shows a linear relation with the environmental concentration.

In the liver compartment (fig 3 ) the n-hexane level reaches a concentration equal to $500 \mu \mathrm{g} / 1(27 \%$ of the saturation concentration) because of the rapid biotransformation of the solvent in this compartment.

When exposure ceases (fig 3 ) the n-hexane concen- 


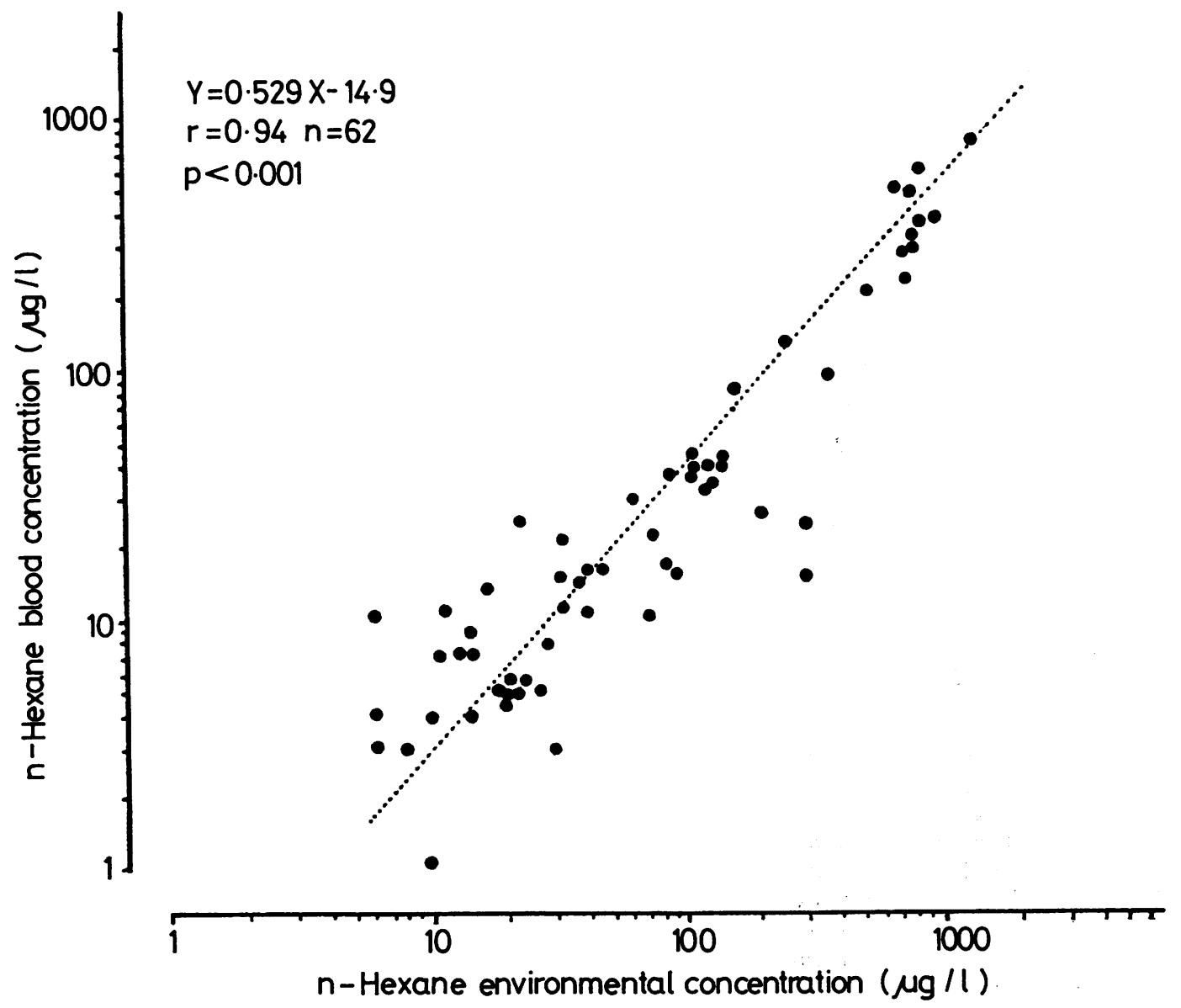

Fig 4 Relation between environmental and venous blood concentrations of $n$-hexane. Data obtained at end of four + four hours workshift.

trations fall in all the compartments: within 10 hours after the end of exposure the venous blood and alveolar concentrations reach such low values than they are difficult to detect by normal methods of analysis.

The $n$-hexane fat concentration rises continuously during exposure and reaches a value of $2578 \mu \mathrm{g} / \mathrm{l}$ at the end. This value is higher than that of the other tissues but corresponds to only $6.9 \%$ of its saturation concentration.

Figure 5 shows the behaviour of the n-hexane concentrations in fat tissue when a daily exposure of eight hours to $360 \mathrm{mg} / \mathrm{m}^{3}$, for five days a week, for two weeks, is simulated. The great solubility of $n$-hexane in this tissue means that the solvent tends to accumulate and the body burden of $n$-hexane cannot be entirely eliminated if exposure is not interrupted for several days (at least $\mathbf{1 0}$ days since the half life of $\mathrm{n}$-hexane in fat tissue corresponds to about 64 hours).
At the end of the second week of exposure, when the maximum level of the solvent in the fat compartment $(9960 \mu \mathrm{g} / \mathrm{l})$ is reached, the fat burden of $\mathrm{n}$-hexane corresponds to $26.6 \%$ of the saturation level.

Figure 6 shows the mean urinary excretion rate of 2,5-HD during 24 hours in a group of 13 shoe factory workers who were occupationally exposed to nhexane for eight hours. The data were obtained as previously described ${ }^{\mathbf{1 9}}$ and necessitated the measurement of environmental exposure and the collection of all urine samples during a 24 hour period. During exposure the excretion rate of 2,5-HD increases progressively and continues for three to four hours after exposure has ceased. Subsequently the excretion rate falls slowly to the level found at the end of exposure. The results suggested by the model fit the mean results obtained from the workers. In fig 6 the dotted lines represent the results obtained from the 


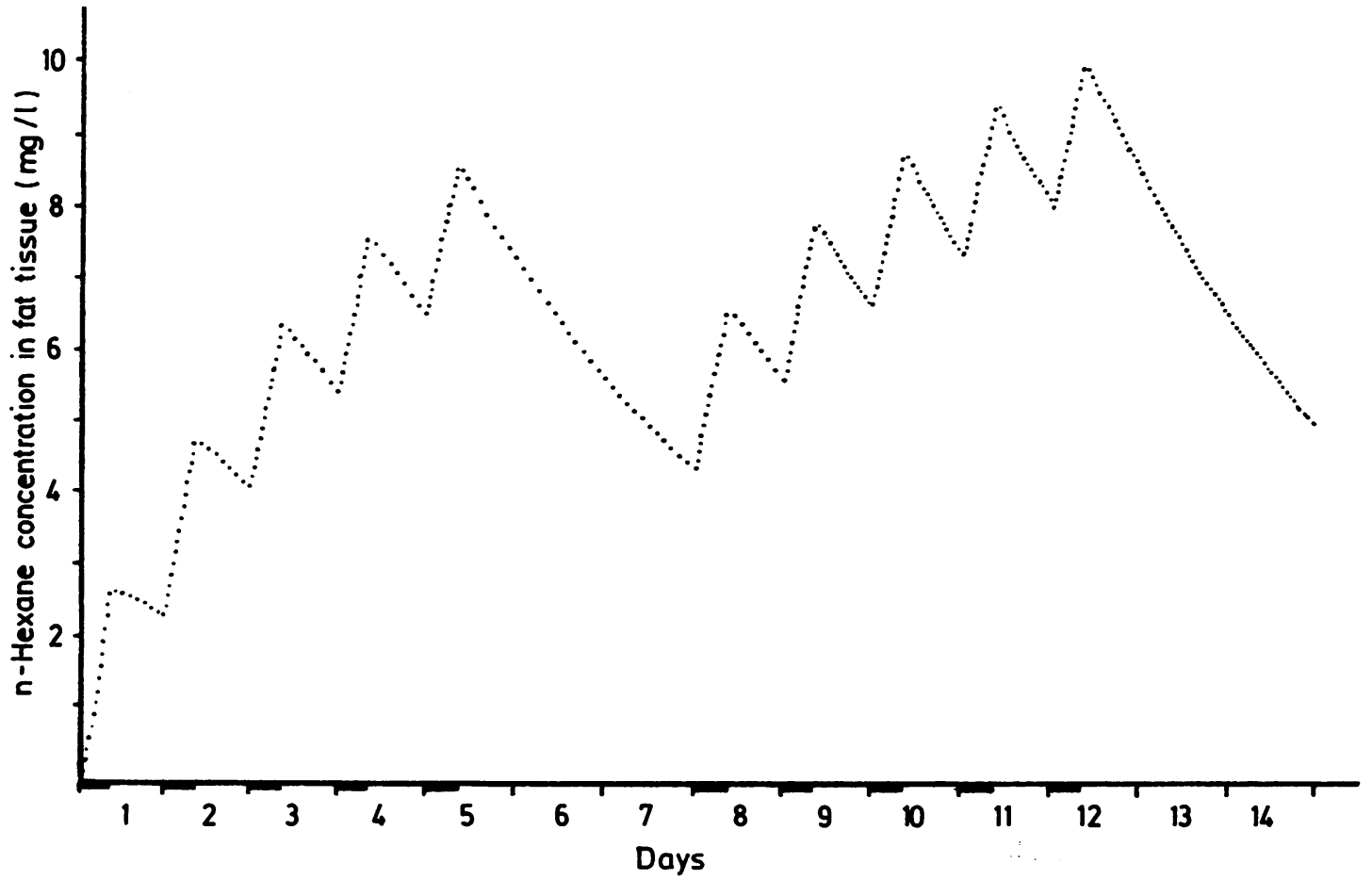

Fig 5 -Hexane concentrations reached in fat tissue during a simulated exposure to $360 \mathrm{mg} / \mathrm{m}^{3}$, for eight hours a day, for five days a week, for two weeks.

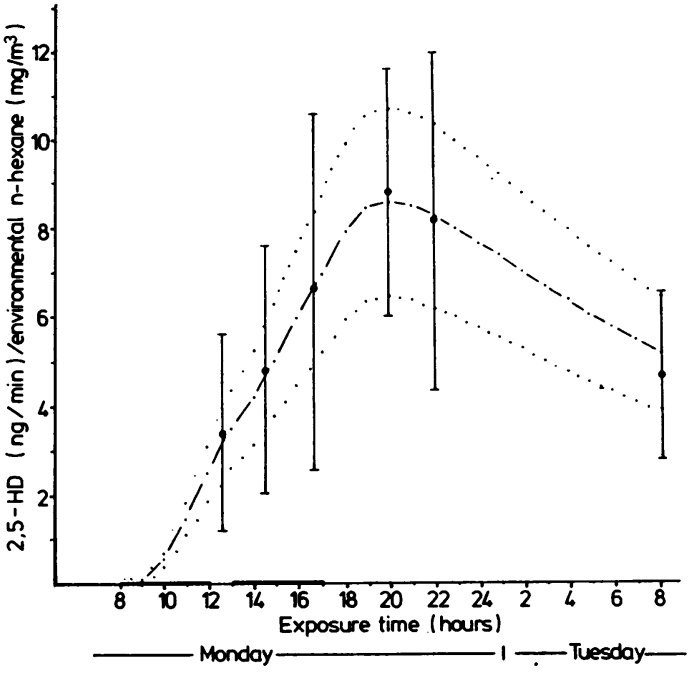

Fig 6 Urinary excretion rate of 2,5-HD in a group of shoe factory workers exposed to n-hexane during workshift. Mean value is represented by black circle (standard deviation by vertical strokes). Data suggested by mathematical model (.......) correspond well to mean excretion rate of 2,5-HD. Dotted lines above and below mean are obtained using $a \mathrm{~K} 2$ equal to 0.016 and 0.009 respectively. model when a K2 equal to 0.009 and 0.016 (instead of 0.012 ) is used.

Simulating an exposure to $360 \mathrm{mg} / \mathrm{m}^{3}$ for eight hours a day for five days, the 2,5-HD excretion rate will be similar to that shown in fig 7 . After the first exposure, the urinary excretion rate of 2,5-HD remains high, although with wide fluctuations; only on Monday morning, before work starts, is the 2,5-HD excretion rate so low that its quantification is uncertain. In the same figure the urinary amount of $2,5-\mathrm{HD}(\mathrm{mg} / 24 \mathrm{~h})$ excreted during each week day is

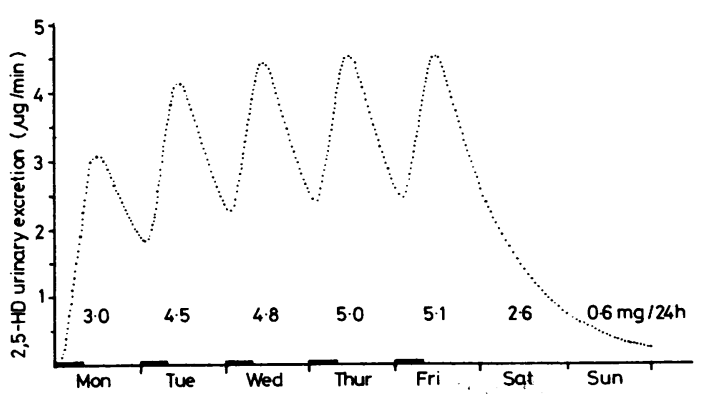

Fig 7 Urinary excretion rate of 2,5-HD suggested by model with a simulated exposure to n-hexane to $360 \mathrm{mg} / \mathrm{m}^{3}$ for eight hours for five days a week. Total amount of 2,5-HD daily excreted is also shown. 
reported. On Monday this value is much lower than on the last working day of the week.

\section{Discussion}

The objective of the present work was to increase knowledge of the toxicology of $n$-hexane by interpreting experimental data collected in industrial workers with the help of a mathematical model.

The biological exposure index (BEI) is attracting the attention of industrial hygienists and some values have been recently suggested by the ACGIH. ${ }^{24}$

Mathematical models can be useful in the study of occupational exposure, can complement field studies and experimental exposures, and can help to understand the uptake, distribution, and excretion of various products. They are helpful when it is necessary to study the time of biological sampling or the physical workload in the solvent uptake or the body burden during different types of exposure (short and high or constant or repeated). The model used here to simulate the kinetics of n-hexane and of 2,5-HD gives many results which are similar to those already reported. The alveolar and venous blood concentrations of $n$-hexane suggested by the mathematical model are similar to those obtained in experimental and occupational exposures. The urinary 2,5-HD excretion found in workers exposed to n-hexane was also correctly simulated by the mathematical calculations. This validation of the model allows us to think that other simulations will also provide some data with a good approximation to those found in vivo.

The data on the kinetics of $n$-hexane in the fat tissues are particularly interesting. The model suggests a $n$-hexane $t \frac{1}{2}$ in the fat tissue equal to 64 hours; it follows from this that the solvent accumulates in the fat compartment and the unexposed period of the weekend is not long enough to allow the complete excretion of the solvent from the fat tissues. The complete excretion of $n$-hexane from fat tissue needs more than 10 days with no further exposure. After occupational exposure, the complete release of $n$ hexane from the fat is not possible during the weekend but requires long absences from work. Similar results were obtained experimentally with other industrial solvents whose blood/fat distribution coefficient is more than $50 .{ }^{25}$

Another useful piece of information suggested by the model relates to the alveolar and venous blood $\mathrm{n}$-hexane concentrations which, 16 hours after a 360 $\mathrm{mg} / \mathrm{m}^{3}$ exposure for eight hours, are so low that their detection is not possible with the usual methods. Moreover, it is improbable that the small amount of $\mathrm{n}$-hexane in these biological samples would be reliable for a correct evaluation of previous exposure. The results concerning the urinary excretion rate of
2,5-HD, obtained with the model are in good agreement with the data obtained from subjects exposed at work. The inference about repeated exposures with a progressive increase of the urinary 2,5-HD during the working week is supported by our previous data ${ }^{19}$ and by those of Arfaioli $e t a^{26}$ and Iwata et al. ${ }^{27}$ These authors found that 2,5-HD is present in urine samples collected 16 hours after exposure to $n$-hexane (on the morning after) and that at the end of the working week, the urinary 2,5-HD concentrations are higher than on the first day of the week (if the exposure is the same). If we consider a urinary excretion of $1 \mathrm{ml} / \mathrm{min}$ the model suggests that on Monday evening at the end of an exposure to $n$-hexane 360 $\mathrm{mg} / \mathrm{m}^{3}$ for eight hours, the $2,5-\mathrm{HD}$ urinary concentration is equal to $1.2 \mathrm{mg} / \mathrm{l}$ (if the urine is collected in a single sample); at the end of the workshift on Friday (with repeated analogous exposure during the other weekdays) the 2,5-HD urinary concentration reaches $3.2 \mathrm{mg} / \mathrm{l}$. Mutti et al found that a urinary 2,5-HD concentration of $3 \mathrm{mg} / \mathrm{g}$ of creatinine corresponded to a mean exposure of $50 \mathrm{ppm}\left(180 \mathrm{mg} / \mathrm{m}^{3}\right){ }^{28}$ Similar data were found by us ${ }^{21}$ and by Iwata $e t a^{27}$ in other groups of workers, but none of the studies considered the possibility of an accumulation of urinary 2,5-HD during the week. Other studies will be necessary to define the BEI of 2,5-HD after exposure to n-hexane but the data suggested by the model should prove useful in this respect. The accumulation of 2,5-HD in the body and in the urine provides an important factor in understanding the mechanisms of the neurotoxicity of $n$-hexane and of other solvents that give rise to 2,5-HD; moreover, any factors that modify the body kinetics of this product will also modify its toxic effects on the peripheral nervous system.

\section{Appendix}

Tissue compartments - The rate of change of $n$-hexane within the three compartments (FG, MG, VRG), where the solvent does not undergo any biotransformation or excretion, is estimated as the difference between the amount of the solvent which reaches the compartment in the arterial blood and the amount of the solvent which leaves the compartment in the venous blood. Bearing in mind that the venous blood concentrations emerging from each compartment are governed by the tissue/blood partition coefficients of the solvent, the differential equation which expresses the rate of $n$-hexane change in the individual compartments is:

$$
\mathrm{dC}(\mathrm{i}) / \mathrm{dt}=\mathbf{Q}(\mathrm{i}) / \mathbf{V}(\mathbf{i})(\mathbf{C}(\operatorname{art})-\mathbf{C}(\mathbf{i}) / \mathbf{N}(\mathbf{i}))
$$

Venous blood concentration-In the mixed venous blood reaching the lungs the concentration of $n$ hexane is calculated as the sum total of the venous 
concentrations emerging from all the compartments according to the following formula:

$$
\mathrm{C}(\text { ven })=(\Sigma \mathrm{Q}(\mathrm{i}) \mathrm{C}(\operatorname{art}) / \mathrm{N}(\mathrm{i})) / \mathrm{Q}(\mathrm{t})
$$

Pulmonary compartment-The concentration of $\mathrm{n}$ hexane in the lung compartment depends on the amount of solvent inhaled, the amount of solvent removed by the pulmonary arterial blood, on the amount of solvent brought by mixed venous blood from the tissues to the lungs, and on the amount of solvent expired. According to this, the rate of change of $\mathrm{n}$-hexane in the pulmonary compartment is given as:

$$
\begin{aligned}
& \mathrm{dA}(\text { lung }) / \mathrm{dt}=\mathrm{Q}(\text { alv }) \mathrm{C}(\text { inh })+ \\
& \mathrm{C}(\text { ven }) \mathrm{Q}(\mathrm{t})-\mathrm{Q}(\text { alv }) \mathrm{C}(\text { alv })-\mathrm{C}(\text { art }) \mathrm{Q}(\mathrm{t})
\end{aligned}
$$

As the pulmonary compartment consists of the lung tissue, the residual functional capacity (RFC), and the arterial blood, the amount of solvent present in the lung compartment may be expressed as follows:

$$
\begin{aligned}
& \mathrm{A} \text { (lung) }=\mathrm{C}(\text { lung }) \mathrm{V} \text { (lung) }+\mathrm{C}(\text { art }) \mathrm{V}(\text { art })+ \\
& \text { C(CFR)CFR }
\end{aligned}
$$

Since $C($ lung $)=C($ art $), C($ alv $)=C(R F C)$ and $C(R F C)=C(\operatorname{art}) / N$, equations (3) and (4) may be expressed as:

$$
\begin{array}{r}
\mathrm{dC}(\text { art }) / \mathrm{dt}=1 /(\mathrm{V} \text { (lung) }+\mathrm{V}(\text { art })+ \\
\mathrm{CFR} / \mathrm{N})(\mathrm{Q} \text { (alv)C(inh) }+\mathrm{C}(\text { ven }) \mathrm{Q}(\mathrm{t})- \\
\mathrm{Q}(\text { alv }) \mathrm{C}(\text { art }) / \mathrm{N}-\mathrm{C}(\text { art }) \mathrm{Q}(\mathrm{t}))
\end{array}
$$

By inserting (for the evaluation of the venous blood concentration of the solvent) equation (2) into (5) we obtain:

$$
\begin{array}{r}
\mathrm{dC}(\text { art }) / \mathrm{dt}=(1 /(\mathrm{V} \text { (lung) }+\mathrm{V}(\text { art })+ \\
\text { CFR/N))(Q(alv)C(inh) }+\Sigma(\mathrm{i}) \mathrm{Q}(\mathrm{i}) \mathrm{C}(\mathrm{i}) / \mathrm{N}(\mathrm{i})- \\
\mathrm{Q}(\text { alv) } \mathrm{C}(\text { art }) / \mathrm{N}-\mathrm{C}(\text { art }) \mathrm{Q}(\mathrm{t}))
\end{array}
$$

which gives the rate of change of the arterial blood n-hexane concentration.

Liver compartments-The liver includes, from the mathematical point of view, two compartments: one for $n$-hexane and the other for its metabolites. The rate of change of n-hexane in the liver is given by equation (1) with the insertion of the biotransformation $\mathrm{n}$-hexane rate constant $\mathrm{K} 1$ :

$$
\begin{array}{r}
\mathrm{dC}(1) / \mathrm{dt}=1 / \mathrm{V}(1)((\mathrm{Q}(1) \mathrm{C}(\mathrm{art})- \\
\mathrm{Q}(1) \mathrm{C}(1) / \mathrm{N}(1))-\mathrm{C}(1) \mathrm{K} 1
\end{array}
$$

The amount of the 2,5-HD present in the liver depends on the n-hexane liver concentration, on the rate of synthesis of 2,5-HD (K2), and on the elimination rate of the 2,5-HD (K3) from the liver into the water compartment:

$$
\mathrm{dA}(1) / \mathrm{dt}=\mathrm{C}(1) \mathrm{V}(1) \mathrm{K} 2-\mathrm{Y}(8) \mathrm{K} 3
$$

Water compartment-The amount of the 2,5-HD present in the water compartment is given by the difference between the amount arriving from the liver compartment and the amount excreted in the urine:

$$
\mathrm{dA}(\mathrm{w}) / \mathrm{dt}=\mathrm{A}(1) \mathrm{K} 3-\mathrm{A}(\mathrm{w}) \mathrm{K} 4
$$

Urine compartment-The rate of change of $2,5-\mathrm{HD}$ in the urine is estimated by the amount of the metabolite emerging from the water compartment:

$$
\mathrm{dA}(\mathrm{u}) / \mathrm{dt}=\mathrm{A}(\mathrm{w}) \mathrm{K} 4
$$

The system of simultaneous differential equations was solved using the Runge-Kutta-Gill method of integration written in Basic on a M24 Olivetti personal computer.

This work was in part supported by the Italian National Research Council (CNR): finalised project on preventive and rehabilitative medicine, subproject SP5, Toxicological Risk, grant No 820213256.

\section{References}

1 Fiserova-Bergerova V, Vlach J, Singhal K. Simulation and prediction of uptake, distribution and exhalation of organic solvent. $\mathrm{Br} J$ Ind Med 1974;31:45-52.

2 Sato A, Nakajima T, Fujiwara Y, Murayama N. A pharmacokinetic model to study the excretion of trichloroethylene and its metabolites after an inhalation exposure. $\mathrm{Br} \mathrm{J}$ Ind $\mathrm{Med}$ 1977;34:56-63.

3 Fernandez JG, Droz PO, Humbert BE, Caperos JR. Trichloroethylene exposure. Simulation of uptake, excretion, and metabolism using a mathematical model. $\mathrm{Br} J$ Ind Med 1977;34:43-55.

4 Droz PO, Guellemin MP. Human styrene exposure. V. Development of a model for biological monitoring. Int Arch Occup Environ Health 1983;53:19-36.

5 Fiserova-Bergerova V. Modeling of inhalation exposure to vapors. uptake, distribution, and elimination. Vols I-II. Cleveland: CRC Press, Inc, 1983.

6 Bischoff KB, Dedrick RL, Zaharko DS, Longstreth JA. Methotrexate pharmacokinetics. J Pharm Sci 1971;60:1128-33.

7 Himmelstein KJ, Lutz RJ. A review of the applications of physiologically based pharmacokinetic modeling. J Pharmacokinet Biopharm 1979;7:127-45.

8 Ramsey JC, Andersen ME. A physiologically based description of the inhalation pharmacokinetics of styrene in rats and humans. Toxicol Appl Pharmacol 1984;73:159-75.

9 Droz PO. The use of simulation models for setting BEIs for organic solvents. Ann Am Conf Ind Hyg 1985;12:339-50.

10 Andersen ME. A physiologically based toxicokinetic description of the metabolism of inhaled gases and vapors: analysis at steady state. Toxicol Appl Pharmacol 1981;60:509-26.

11 Eger EI. Anesthetic uptake and action. Baltimore: Williams and Wilkins Co, 1974.

12 Mapleson WW. Circulation-time models of the uptake of inhaled anaesthetics and data for quantifying them. $\mathrm{Br} J$ Anaesth 1973;45:319-34.

13 Perbellini L, Brugnone F, Caretta D, Maranelli G. Partition coefficient of some industrial aliphatic hydrocarbons (C5-C7) in blood and human tissues. $\mathrm{Br} J$ Ind Med 1985;42:162-7.

14 Bohlen P, Schlunegger UP, Lauppi E. Uptake and distribution of hexane in rat tissues. Toxicol Appl Pharmacol 1973;25:242-9.

15 Wagner JG. Method for estimating rate constants for absorption, metabolism, and elimination from urinary excretion data. $J$ Pharmacol Sci 1967;56:489-94.

16 Hilderbrand RL, Andersen ME. In vivo kinetic constants for the metabolism of inhaled hydrocarbon toxicants as determined by gas uptake methods. Toxicologist 1981;1:86-7. 
17 Brugnone F, Perbellini L, Grigolini L, Apostoli A. Solvent exposure in a shoe upper factory. I. $n$-Hexane and acetone concentration in alveolar and environmental air and in blood. Int Arch Occup Environ Health 1978;42:51-62.

18 Baker TS, Rickert DE. Dose-dependent uptake, distribution, and elimination of inhaled n-hexane in the Fischer-344 rat. Toxicol Appl Pharmacol 1981;61:414-22.

19 Perbellini L, Bartolucci GB, Brugnone F, De Rosa E, Valentini F. Il 2,5-esandione nel controllo biologico dell'esposizione professionale a n-esano. Med Lav 1985;76:35-43.

20 Perbellini L, Amantini MC, Brugnone F, Frontali N. Urinary excretion of $\mathbf{n}$-hexane metabolites. A comparative study in rat, rabbit and monkey. Arch Toxicol 1982;50:203-15.

21 Perbellini L, Brugnone F, Faggionato G. Urinary excretion of the metabolites of $\mathrm{n}$-hexane and its isomers during occupational exposure. Br J Ind Med 1981;38:20-6.

22 Bus JS, Deyo D, Cox M. Disposition of radioactivity in rats after acute inhalation exposure to $14 \mathrm{C}$-n-hexane. Toxicologist 1981;1:135.

23 Veulemans H, Van Vlem E, Jansses H, Masschelein R, Leplat A.
Experimental human exposure to $n$-hexane: study of the respiratory uptake and elimination, and of $\mathrm{n}$-hexane concentrations in peripheral venous blood. Ind Arch Occup Environ Health 1982;49:251-63.

24 American Conference of Governmental Industrial Hygienists. Threshold limit values for chemical substances and physical agents in the work environmental and biological exposure indices with intended changes for 1984-85. Cincinnati: ACGIH, 1984.

25 Engstron J. Styrene in subcutaneous adipose tissues after experimental and industrial exposure. Scand $J$ Work Environ Health suppl 1978;2:119-20.

26 Arfaioli C, Bavazzano P, Biancalani P, et al. Utilizzazione del 2,5-esandione urinario nel monitoraggio biologico degli esposti a n-esano.48 Congr Naz Soc Ital Med Lav Igiene Ind. Pavia 18-21 Sept 1985, Monduzzi (Bologna) 1985.

27 Iwata M, Takeuchi Y, Hisanaga N, Ona Y. A study on biological monitoring of n-hexane exposure. Int Arch Occup Environ Health 1983;51:253-60.

28 Mutti A, Falzoi M, Lucertini S, et al. n-Hexane metabolism in occupationally exposed workers. Br J Ind Med 1984;41:533-8.

\section{Vancouver style}

All manuscripts submitted to the $\mathrm{Br} J$ Ind $\mathrm{Med}$ should conform to the uniform requirements for manuscripts submitted to biomedical journals (known as the Vancouver style).

The $\mathrm{Br} J$ Ind Med, together with many other international biomedical journals, has agreed to accept articles prepared in accordance with the Vancouver style. The style (described in full in $\mathrm{Br}$ Med J, 24 February 1979, p 532) is intended to standardise requirements for authors.

References should be numbered consecutively in the order in which they are first mentioned in the text by Arabic numerals above the line on each occasion the reference is cited (Manson ${ }^{1}$ confirmed other reports ${ }^{2-5} \ldots$ ). In future references to papers submitted to the $B r J$ Ind Med should include: the names of all authors if there are six or less or, if there are more, the first three followed by et al; the title of journal articles or book chapters; the titles of journals abbreviated according to the style of Index Medicus; and the first and final page numbers of the article or chapter.

Examples of common forms of references are:

${ }^{1}$ International Steering Committee of Medical Editors. Uniform requirements for manuscripts submitted to biomedical journals. Br Med J 1979;1:532-5.

- Soter NA, Wasserman SI, Austen KF. Cold urticaria: release into the circulation of histamine and eosinophil chemotactic factor of anaphylaxis during cold challenge. N Engl J Med 1976;294:687-90.

${ }^{3}$ Weinstein L, Swartz MN. Pathogenic properties of invading micro-organisms. In: Sodeman WA Jr, Sodeman WA, eds. Pathologic physiology: mechanisms of disease. Philadelphia: W B Saunders, 1974:457-72. 